\title{
Strategic Planning Process Intensity and Formality Impact on the Performance of Accredited Universities in Kenya
}

\author{
Christine A. Kabui ${ }^{1}$, Vincent N. Machuki ${ }^{2}$, John K. Yabs ${ }^{3}$ \& James M. Njihia ${ }^{4}$ \\ ${ }^{1}$ School of Business and Economics, South Eastern Kenya University, Kenya \\ ${ }^{2}$ School of Business, University of Nairobi, Kenya \\ Correspondence: Christine A. Kabui, School of Business and Economics, South Eastern Kenya University, \\ Kenya. E-mail: ackabui@yahoo.com
}

Received: June 23, 2018

doi:10.5539/ijbm.v13n9p153
Accepted: July 21, 2018

Online Published: August 1, 2018

URL: https://doi.org/10.5539/ijbm.v13n9p153

\begin{abstract}
This study sought to investigate if the strategic planning process has significant influence on the performance of accredited universities in Kenya. Beyond the strategic plan document, the intensity and formality with which the process of strategic planning is carried out, its extensiveness and inclusiveness, is a concern for organizations in the twenty first century. Performance of accredited universities was conceptualized into growth and ranking as guided by the world standard for performance of tertiary institution. The study is anchored on the institutional theory and contingency theory. This study is founded on the positivist philosophical orientation as it is founded on theory and it adopted a descriptive cross sectional survey design. The population of interest was all accredited universities in Kenya as at November 2016. The findings indicate a statistically significant direct relationship between strategic planning process and growth $\left(\mathrm{F}=2.605, \mathrm{p}=0.047\right.$ and $\left.\mathrm{R}^{2}=.303\right)$ and with ranking $(\mathrm{F}=1.995$, $\mathrm{p}=0.033$ and $\mathrm{R}^{2}=0.218$ ). Engaging university stakeholders in the strategic planning process and focusing the energies of members on the seven key variables of the strategic planning process should be encouraged and enhanced while engaging in a strategic planning process that is formal, this is in an effort to ensure that formality is balanced with allowing room for creativity and avoid missing out on innovative approaches from members. Further research in to other industries with different performance measures and the use of longitudinal design are possible areas for further research to enhance generalization of current findings.
\end{abstract}

Keywords: strategic planning process, intensity, formality, growth, ranking, performance, accredited universities, Kenya

\section{Introduction}

Strategic planning process is commonly used by organizations to respond to and manage change. Over the years, long range planning was used to enhance organization performance and it yielded superior results with planners out performing none planners (Thune \& House, 1970). In the 1970's there were drastic and unpredictable changes in the business environment, both internally and externally, which made it impractical for organizations to extrapolate their future from past success leading to the decline in the emphasis laid on planning (Mintzberg, 1978). During the period of retrenchment however, the recasting of planning focused on the need to carry out strategic planning which incorporates the environmental analysis and leaves room for contingent plans (Ansoff \& Suvillan, 2003). The $21^{\text {st }}$ century has seen a rise in the need to focus closely, not just on the production of a strategic plan document but also have an intense and inclusive process which is formal and comprehensive enough (Chavunduka, Chimunhu, \& Sifile 2015). In light of this, it is not just having a strategic plan for an organization but going through the strategic planning process that counts since strategic planning process formality and intensity may have a possible effect on performance of organizations.

Strategic planning process as a management tool that organization management can use to enhance performance is supported by the postulation of Institutional theory (Dumaine, 1989; North, 1990) that institutionalization is both a process and a property variable (Freeman, 1994). It is a process since it is continuous rather than a one off activity and property because it is based on what the organization already possess. This is complemented by contingency theory (Lawrence \& Lorsh, 1967; Carlisle, 1976), which is an approach of studying organization behavior in which the design and function of organizations and organization outcome are the consequence of a mix of two or more contingent factors. 
The chartered universities in Kenya play a significant role in the socio-economic development of Kenya and the region, therefore, their performance is of critical importance. McCormack et al., (2013) argues that performance of universities, in both research and education matters. Faced with ever growing, complex myriad of forces inside and outside of the realm of academia, universities need to develop programs and policies in response to globalization. This is in an effort to reach acceptable international standards, taking advantage of opportunities offered by environment since global rating ranks Universities based on various output measures (UNESCO, 2013). The measurement of performance at universities in Kenya is based on growth in programs, student enrollment and graduation rate at the levels of undergraduate, master and doctoral (CUE, 2016) in addition to ranking.

\section{Literature Review and Hypothesis}

A primary research objective in strategic management is explaining and predicting organizational performance (Ketchen \& Thomas, 1996). The particular interest of strategy researchers is performance implications of major decisions that are made in anticipation of, or in response to, environmental conditions (Ketchen \& Thomas, 1996; Arasa, 2008; Gould \& Power, 2015). Wu (2009) defines organizational performance as how well the organization is managed and the value it delivers to its stakeholders, which is achieved when it achieves its expected objectives with greater efficiency and effectiveness than competitors (Daft, 2000; Letting, 2011). Performance assures that organization contributes to its mission and remains responsive to stakeholder needs (Baysinger \& Hoskisson, 1990; Kinuu, 2014). Heffernan and Flood (2000) argue that performance does not only mean defining problem but also solution to problem.

Studies on the effect of strategic planning on organization performance have presented mixed findings. Ramanujan, Venkatraman and Camillus (1986) found that a key effect of formal planning is that it alters specific elements of the overall strategic decision process hence associated with adopting key steps in decision process. For Miller and Cardinal (1994), planning was found to strongly and positively relate to growth in studies in which industry effect were controlled, an informant source of performance data was used, planning was defined as not requiring written documentation and the quality of assessment strategy was high while explicit strategies are dysfunctional as they channel attention and behavior to specific plans thereby driving out important innovations and creativity. Boyne et al., (2003) observes that planning is believed to lead to positive organizational outcome due to the clarity of objectives, provision of framework to allocate resources and communication to all staff. Gibson and Cassar (2005) found a negative relationship between planning and performance of small and medium enterprises while Boyd (1991) in his meta-analytical review found a modest relationship between planning and performance.

The strategic planning process is evolving in its response to increasing rate of change in the business environment (Bryson, 2004). Formal and intensive strategic planning is a significant tool that can be used by decision makers to deliver superior performance expected by stakeholders (Chavunduka, 2015) while Ranasinghe (2010) finds that some elements of planning intensity and formality of planning process, positively impacts performance. Further empirical investigations in different industry contexts, using non-financial performance measures and focusing on the strategic planning process will facilitate consensus building. Does strategic planning process formality and intensity influence performance of universities in Kenya?

Institutional theory (North, 1990) at its core is explaining aspects of social structures, how they are formed, shared, adapted and adopted over a period of time and by people operating in the same institution (Amenta, 2005). Meyer and Rogan (1991) argue that sometimes organizations will adopt some structural forms that do not necessarily improve efficiency in order to gain or maintain legitimacy in the institutional environment which in turn ensures organizational survival. However these formal structures of legitimacy can reduce efficiency and hinder organizations competitive position in the technical environment. DiMaggio and Powell $(1983,1991)$ conclude that institutional pressure will led organizations into a need for homogeneity in their structures which is as a result of coercive, mimetic and normative pressure. Drawing on the postulations of the theory, performance increases organization legitimacy because it shows how well the organization is fulfilling its roles in society and it is not always about the monetary return but more so the increased stakeholder satisfaction in line with organization set vision and mission. Do Kenya universities yield a positive impact on their performance as a result of engaging in the strategic planning process since they all have strategic plans?

Hypothesis: Strategic planning process formality and intensity has significant influences on performance of accredited universities in Kenya

\section{Methods}

This study is anchored in the positivist philosophical orientation as it is founded on theory. It is largely involved 
in theory testing, and it seeks to respond to research hypotheses and empirically establishing a link among study variables (Cooper \& Schindler, 2004; 2006). The key idea of positivism is that the social world exists externally and its properties should be measured objectively rather than being inferred subjectively (Creswell, 2012). It uses existing theory to develop hypotheses which are tested and confirmed in whole or in part or are refuted, thus informing and guiding further development of theory which is continually tested (Saunders et al., 2007; Rileys, 2000). The study adopted a descriptive cross sectional survey design where data were collected across universities in Kenya at one point in time helping the researcher establish whether significant association exist among variables at such point in time (Cooper \& Schindler, 2006; Nachmias \& Nachmias, 2004; Bryman \& Bell, 2003) leading to study conclusion and recommendations.

The population of interest for this study was all 70 accredited universities in Kenya (CUE, 2016). Primary data on the formality and intensity of the strategic planning process was collected using a questionnaire administered to the university registrar planning and development through the "drop and pick later" method. Secondary data on university performance was collected from the MoEST reports, CUE reports and international web ranking reports. The instrument was reliable with values of between 0.539 and 0.937 on Cronbach alpha. A response rate of $61.5 \%$ was realized. Diagnostic tests on normality, linearity, multicolinearity and homoscedasticity were done and they all confirmed suitability of the data set for further empirical analysis. Data was analyzed using regression analysis to establish the effect of strategic planning process intensity and formality on growth and on ranking of universities. The regression model is stated as;

$$
\mathrm{P}=\mathrm{f} \text { (Strategic planning process); } \mathrm{P}_{1=} \beta_{01}+\beta_{11} \mathrm{X}_{11}+\beta_{12} \mathrm{X}_{12}+\varepsilon \text { And } \mathrm{P}_{2}=\beta_{011}+\beta_{111} \mathrm{X}_{11}+\beta_{122} \mathrm{X}_{12}+\varepsilon
$$

Where $\mathrm{P}=$ Performance of accredited universities ( $\mathrm{P}_{1=}$ Growth; $\mathrm{P}_{2}$ Ranking); $\mathrm{X}_{11}=$ Strategic planning process Intensity; $X_{12}=$ Strategic planning process Formality; $\varepsilon=$ Error term and $\beta_{01}, \beta_{11}, \beta_{12}, \beta_{011}, \beta_{111}, \beta_{122}=$ Coefficients

Table 1. Operationalization of Study Variables

\begin{tabular}{|c|c|c|}
\hline Variable & Operational Definition and Indicators & Supporting Literature \\
\hline \multirow{6}{*}{$\begin{array}{l}\text { Strategic Planning } \\
\text { Process } \\
\text { (Independent Variable) }\end{array}$} & Planning Intensity & Hopkins and Hopkins, 1977 \\
\hline & $\begin{array}{l}\text { Emphasis laid in the variables of the strategic planning process, } \\
\text { focused energy and integration }\end{array}$ & $\begin{array}{l}\text { Aosa, 1992; Burnside, 2002; Arasa, } \\
\text { 2008; }\end{array}$ \\
\hline & - $\quad$ Planning Formality & Chavunduka, 2015 \\
\hline & (Process orientation) & Ranasinghe, 2010 \\
\hline & Written documents and explicitly stated objectives & \\
\hline & $\begin{array}{l}\text { Extensiveness, rationality and comprehensiveness of planning } \\
\text { process }\end{array}$ & \\
\hline \multirow{3}{*}{$\begin{array}{l}\text { Organizational/ University } \\
\text { Performance } \\
\text { (Dependent Variable) }\end{array}$} & SBSC Operationalized & 1992,1998, \\
\hline & $\begin{array}{l}\text { Growth in, student numbers, program numbers, graduation rates } \\
\text { and }\end{array}$ & Figgee,2002; Hubbard, 2009 \\
\hline & Ranking in Web metric local and international & \\
\hline
\end{tabular}

\section{Results and Findings}

The findings on strategic planning process intensity show the mean ranged between 3.1 and 3.6, majority of the t-values were significant at 95\% confidence level and the CV ranged between 24 and $27 \%$. This indicates that across universities, the intensity with which they engage in the strategic planning process is to a moderate extent as shown by mean with some mild variation across universities as shown by the coefficient of variation. Strategic planning process formality has mean ranging between 3 and 4.3 and CV ranged between 18 to $34 \%$. This indicates that the degree of formality of the strategic planning process across universities ranges from moderate towards great extent as indicated by the mean with moderate variation across universities as indicated by the coefficient of variation. For university performance; $75 \%$ of the universities have had moderate to very high growth rate in the last three years with $20 \%$ experiencing a growth rate of below $1 \%$ per year. $67.5 \%$ of the universities ranked top forty in the Kenya ranking which ranked all tertiary institutions in Kenya and only $10 \%$ were ranked among the last twenty institutions.

Strategic planning process is a good predictor of growth of universities as indicated by a significant F-value at $95 \%$ confidence level and an $\mathrm{R}$ value of 0.427 . Thirty percent of variation of growth at accredited universities in Kenya is explained by strategic planning process as indicated by $\mathrm{R}^{2}$ and this is a moderate relationship. The degree of formality of the strategic planning process at the universities has an inverse relationship with the 
growth the institution as indicated by a negative beta coefficient for formality while intensity has a direct relationship as indicated by positive beta coefficients.

Table 2. Strategic planning process and Growth

\begin{tabular}{|c|c|c|c|c|c|c|c|c|}
\hline \multicolumn{9}{|c|}{ Model Summary ${ }^{\mathrm{b}}$} \\
\hline \multicolumn{2}{|c|}{ ModelR } & \multirow{2}{*}{$\begin{array}{l}\text { R Square } \\
.303\end{array}$} & \multicolumn{4}{|c|}{ Adjusted R SquareStd. Error of the Estimate } & & \multirow{2}{*}{$\begin{array}{l}\text { Durbin-Watson } \\
1.446\end{array}$} \\
\hline 1 & $.427^{\mathrm{a}}$ & & .228 & 1.16895 & & & & \\
\hline \multirow{2}{*}{\multicolumn{9}{|c|}{$\begin{array}{l}\text { a. Predictors: (Constant), Planning Intensity, Planning Formality } \\
\text { b. Dependent Variable: Growth Performance }\end{array}$}} \\
\hline & & & & & & & & \\
\hline \multicolumn{9}{|c|}{ ANOVA $^{\text {a }}$} \\
\hline \multicolumn{2}{|c|}{ Model } & \multicolumn{2}{|c|}{ Sum of SquaresDf } & \multicolumn{2}{|l|}{ Mean Square } & \multicolumn{2}{|l|}{$\mathrm{F}$} & \multirow{4}{*}{$\begin{array}{ll}\text { Sig. } \\
.047^{\mathrm{b}}\end{array}$} \\
\hline \multirow[t]{3}{*}{1} & \multicolumn{2}{|c|}{ Regression5.627 } & 3 & 2.876 & & \multirow[t]{3}{*}{2.605} & & \\
\hline & Residual & 49.192 & 36 & 1.366 & & & & \\
\hline & Total & 54.819 & 39 & & & & & \\
\hline \multicolumn{9}{|c|}{ a. Dependent Variable: Growth Performance } \\
\hline \multicolumn{9}{|c|}{ b. Predictors: (Constant), Planning Intensity, Planning Formality } \\
\hline \multicolumn{9}{|c|}{ Coefficients $^{\mathrm{a}}$} \\
\hline & & & \multicolumn{2}{|c|}{ Unstandardized Coefficients } & \multicolumn{3}{|c|}{ Standardized Coefficients } & \\
\hline \multicolumn{3}{|c|}{ Model } & $\mathrm{B}$ & Std. Error & Beta & & $\mathrm{T}$ & Sig. \\
\hline \multirow[t]{3}{*}{1} & \multicolumn{2}{|l|}{ (Constant) } & 2.222 & 1.626 & & & 1.650 & .003 \\
\hline & \multicolumn{2}{|c|}{ Planning Intensity } & .989 & .537 & .467 & & 1.843 & .013 \\
\hline & \multicolumn{2}{|c|}{ Planning Formality } & -1.577 & .640 & -.735 & & -2.465 & .427 \\
\hline
\end{tabular}

a. Dependent Variable: Growth Performance

Strategic planning process is a good predictor of ranking performance as indicated by an R value of $0.377 .22 \%$ of variation in ranking performance of accredited universities can be explained by variation in strategic planning process as indicated by $\mathrm{R}^{2}$. The $\mathrm{t}$-values are all significant at $95 \%$ confidence level indicating that the operationalization of the strategic planning process are good predictors of ranking performance of universities. Planning intensity has a direct positive relationship with ranking performance while formality of the plan has an inverse relationship with ranking performance.

Table 3. Strategic planning process and Ranking

\begin{tabular}{|c|c|c|c|c|c|c|c|}
\hline \multicolumn{8}{|c|}{ Model Summary ${ }^{b}$} \\
\hline Model & $\mathrm{R}$ & R Square & \multicolumn{2}{|c|}{ Adjusted R Square } & Std. Error of the Estimate & \multicolumn{2}{|c|}{ Durbin-Watson } \\
\hline 1 & $.377^{\mathrm{a}}$ & .218 & \multicolumn{2}{|c|}{.140} & 1.38110 & \multicolumn{2}{|l|}{1.684} \\
\hline \multicolumn{8}{|c|}{ a. Predictors: (Constant), Planning Intensity, Planning Formality } \\
\hline \multicolumn{8}{|c|}{ b. Dependent Variable: Ranking Performance } \\
\hline \multicolumn{8}{|c|}{ ANOVA $^{a}$} \\
\hline \multicolumn{2}{|l|}{ Model } & \multicolumn{2}{|c|}{ Sum of Squares } & df & Mean Square & $\mathrm{F}$ & Sig. \\
\hline \multirow[t]{3}{*}{1} & Regression & 8.158 & & 3 & 2.719 & 1.995 & $.033^{\mathrm{b}}$ \\
\hline & Residual & 63.785 & & 36 & 1.772 & & \\
\hline & Total & 71.944 & & 39 & & & \\
\hline \multirow{2}{*}{\multicolumn{8}{|c|}{ a. Dependent Variable: Ranking Performance }} \\
\hline & & & & & & & \\
\hline \multicolumn{8}{|c|}{ Coefficients $^{\mathrm{a}}$} \\
\hline \multirow[b]{3}{*}{ Model } & & & \multicolumn{5}{|c|}{ Standardized } \\
\hline & & & \multicolumn{2}{|c|}{ Unstandardized Coefficients } & Coefficients & & \\
\hline & & & $\mathrm{B}$ & Std. Error & Beta & $\mathrm{t}$ & Sig. \\
\hline \multirow[t]{3}{*}{1} & (Constant) & & 2.957 & 1.522 & & 1.942 & .019 \\
\hline & Planning In & & .677 & .495 & .362 & 1.368 & .118 \\
\hline & Planning Fo & & -.686 & .585 & -.364 & -1.172 & .025 \\
\hline
\end{tabular}

a. Dependent Variable: Ranking Performance 


\section{Discussion}

Universities in Kenya have documented their strategic plan which shows what they envision to become in future both in the short run and in the long run. This compares to a study by Johnson and Scholes (1999) in exploring corporate strategy of large enterprises in United States who finds that the deliberate use of strategy has significant effect on performance of business providing long term direction and development for organizations and a study by Caeldries and Dierdonk (1988) on the effects of strategic planning on eighty two Belgian firms who finds that planning safeguards competitive position, allows better understanding of environment especially competitors in socio-economic trends, intra organizational coordination and creating consensus, better communication flow with integrated behavior and motivation of members as they are allowed to participate in determining the future of the organization. At the universities, the more intense the strategic planning process is especially in the participatory planning, the more it impacts the performance positively as members feel part of the strategic moves envisioned.

The intensity of the strategic planning process among the universities has a significant positive effect on the growth of universities while the degree of formality of the process has a significant inverse relationship to the performance of universities. This compares to the findings of a study by Chavunduka et al. (2015) in Zimbabwe mining firms that find a positive relationship between all the strategic planning intensity factors and overall performance. The performance of universities is however non-financial incorporating growth and ranking. Ranasinghe (2010) in a study of Sri Lanka firms finds that some elements of planning intensity and formality of planning process positively impacts corporate performance this contradicts the findings at the universities in Kenya where strategy planning process intensity positively affects performance while the degree of formality has an inverse relationship to performance. Mintzberg (1983) argues that planning limits creativity and found a negative relationship between planning and performance, this is in line with the findings at the universities in Kenya.

Pearce II et al. (1987) finds that the intensity with which banks engage in the strategic planning process has a direct and positive effect on the banks financial performance which concurs with the findings at the universities though the performance measures were non-financial. The intensity of planning is a credible signal for the importance which an organization members focuses their attention and energy in the learning process. Ugboro et al., (2015) in an empirical study of large manufacturing firms find a positive correlation between degree of formality and the organization performance which contradicts the findings at the university where formality has an inverse effect on the performance, that the more précises the strategic planning process, the more stiff the organization hence adverse effect on performance.

The study findings relate and confirm the postulations of the institutional theory in that, as the expectation for legitimacy, universities will engage in strategic planning process and have a document of the strategic plan. Though it is a call for legitimacy, strategic planning process alters the specific elements of the overall strategic decision process associated with adopting key steps. This is good for clarity and governance but can be limiting to creativity and innovation. The intensity and formality with which each university engages in the planning process is a function of normative force in the institutional theory as a continued desire to remain professional and credible in university operations.

\section{Conclusion}

This study focus was on the intensity and formality with which universities engage in the strategic planning process over and above just having the strategic plan document. Engaging university stakeholders in the strategic planning process and focusing the energies of members on the seven key variables of the strategic planning process should be encouraged and enhanced since it has statistically significant influence on the performance of universities. In addition, universities need to be sensitive while engaging in a strategic planning process that is formal, this is in an effort to ensure that formality is balanced with allowing room for creativity and avoid missing out on innovative approaches from members. When individual members in the university setup have clear mandate on what is expected of them in terms of tasks to be performed, they have clear timelines and precise indicators of when set goals have been achieved, this will directly impact how they are able to contribute to the university mission and work towards achievement of set objectives and goals.

Strategic planning process has a significant positive effect on performance of accredited universities and explains about thirty seven percent of variation in ranking and forty two percent of variation in growth at $95 \%$ confidence level. This finding indicates there are other factors which affect the growth and ranking of universities in addition to strategic planning process. These findings relate to Thune and House (1970) who argue that it is more likely that formal planning is a characteristic of a well-managed organization than the single cause of successful 
organization performance as much as formal planning organizations outperform informal planners.

\subsection{Implications}

The intensity and formality with which the universities engage in the strategic planning process has a significant effect on their performance. It is important that the MoEST and the CUE in their policy formulation efforts continually encourage universities to have strategic planning process that is inclusive of most if not all stakeholders especially the teaching and non-teaching members of staff for when they are involved in the planning process, they easily join in and own the implementation gearing the achievement. There is need to support universities especially in terms of policy on completion or graduation rate since as evidenced from the findings, there is a large discrepancy between the enrollment level and the completion rate. The ranking of Kenya universities at a global level is mainly average tending toward below average; this calls for policy on how to improve the quality of research and the dissemination of findings with an aim of improving the web ranking performance.

\subsection{Limitations of the Study and Suggestions for Further Research}

The study findings are a significant relationship between strategic planning process and performance of accredited universities in Kenya. Study was limited to accredited universities as listed by the CUE. Therefore, the findings of this study are best applicable to universities and may not be accurately generalized to other sectors. Industry specific studies enhance internal validity of the study but there is need for caution when generalizing findings to different industry context. An extension of research into other industries with different performance measures to enhance comparison of findings will facilitate the possibility of generalizing the findings across industry since current study focused on the education sector which has unique and non-financial performance measures.

The use of cross-sectional research design for the study is another limitation since respondents gave their assessment of the given questionnaire statements only once and at a specific time. The choice of the design was informed by the fact that it offers an advantage in terms of cost, control and time plus other strategic planning process studies used it (O'Sullivan \& Abela, 2007; Ranasinghe, 2010; Chavunduka et al., 2015). Hence whereas strategic planning process and organizational performance are dynamic in nature, current study presents a cross-sectional view. A longitudinal study which will compare the execution of the strategic planning process over several years and the impact this has on the performance of the universities over the years will be an extension in knowledge because it is dynamic and could explain why and how best practices are adopted, others adapted to change while some have been discarded.

\section{References}

Ansoff, I., \& Suvillan A. (2003). Optimizing profitability in turbulent environment: A formula for strategic success. Long Range Planning, 26(5), 11-23. https://doi.org/10.1016/0024-6301(93)90073-O

Arasa, R. (2008). Strategic Planning, Employee participation and Organizational Performance in Kenya Insurance (Unpublished PhD Thesis). University of Nairobi, Nairobi.

Boyd, B. (1991). Strategic planning and financial performance: A meta-analytical review. Journal of Management studies, 28, 353-374. https://doi.org/10.1111/j.1467-6486.1991.tb00286.x

Boyne, G., \& Gould-Williams, J. (2003). Planning and Performance in Public Organizations an empirical analysis. Public Management Review, 5(1), 115-132. https://doi.org/10.1080/146166702200002889

Bryman, A., \& Bell, E. (2003). Business Research Methods. Oxford. Oxford University Press

Bryson, J (2004). Strategic planning for public and nonprofit organizations (3rd ed.). San Francisco, CA: Jossey-Bass

Caeldries F., \& Dierdonck, R. (1988). How Belgian business make strategic planning work. Long Range Planning, 21(2), 41-51. https://doi.org/10.1016/0024-6301(88)90121-5

Chavunduka, D., Chimunhu, P., \& Sifile, O. (2015). Strategic Planning intensity and organizational performance: A case of Zimbambwe mining development corporation. European Journal of Business and Management, $7(5), 40-64$.

Commission for University Education- Kenya. (2014). Universities Authorized to operate in Kenya.

Commission for University Education. (2014). Comparative Analysis of Higher Education Systems. Nairobi, Kenya.

Commission for University Education-Kenya. (2013). The commission for university education strategic plan 
2014-2018. Nairobi, Kenya; Government Press.

Cooper, D., \& Schindler, P. (2006). Marketing Research. New York: McGraw-Hill.

Cooper, R., \& Schindler, S. (2003). Business Research Methods (8th ed.). Boston Irwin McGraw-Hills.

Creswell, J. (2012). Qualitative Inquiry and Research Design: Choosing Among Five Approaches: India: Sage Publications.

Daft, R. (2000). Organizational theory and design ( $7^{\text {th }}$ ed.). South western college publishing. Thompson learning U.S.A.

DiMaggio, P., \& Powell, W. (1983). "The iron cage." Institution Isomorphism and collective rationality in organizational field. American Sociological Review, 48, 147-160. https://doi.org/10.2307/2095101

Dumaine, B. (1989). How managers can succeed through speed. Fortune, 199(4), 54.

Freeman, R. E., Wicks, A. C., \& Parmar, B. (2004). Stakeholder theory and the corporate objectives revisited. Organization Science, 15(3), 364-369. https://doi.org/10.1287/orsc.1040.0066

Gloud, E. M. (2015). The plan is to Act. Journal of Agricultural management, 73(2), 90-93.

Hardy, C., Langley, A., Mintzberg, H., \& Rose, J. (1983). Strategy formation in the university setting. The Review of Higher Education, 6(4), 407-433. https://doi.org/10.1353/rhe.1983.0015

Heffernan, M., \& Flood, P. (2000). An exploration of the relationship between managerial competencies, organizational characteristics and performance in an Irish organization. Journal of European Industrial Training, 128-136. https://doi.org/10.1108/03090590010321098

Johnson, G., \& Scholes, K. (1984). Exploring corporate strategy. Prentice Hall International.

Ketchen, D., David, J., Thomas, J., \& James, B. (1996). Process, Content and Context: Synergistic effect on Organizational performance. Journal of Management. https://doi.org/10.1177/014920639602200203

Lawrence, P. R., \& Lorsh, S.W. (1967). Differentiation and integration in complex organizations. Administrative science quarterly, 12(1), 1-47. https://doi.org/10.2307/2391211

Lawrence, P., \& Lorsh, J. (1967). Organization and Environment; Managing differentiation and Integration. Boston MA. Havard Business School.

Letting, N. (2011). Board of Directors'Attribute, Strategic Decision - Making and Corporate performance of firms listed on the Nairobi stock exchange (unpublished PhD Thesis). University of Nairobi, Nairobi.

McCormack, J., Proper, C., \& Smith, S. (2014). Herding Cats? Management and University performance. Economic Journal Working paper, 124(578), 534-564. https://doi.org/10.1111/ecoj.12105

Meyer, D. (1991). What is strategy's distinctive competencies? Journal of Management, 17, 821. https://doi.org/10.1177/014920639101700413

Miller, C., \& Cardinal, L. (1994). Strategic planning and organizational performance: A synthesis of more than two decades of research. Academy of Management Journal, 37, 1649-1665.

Mintzberg, H. (1978). Patterns in strategy formation. Management science, 24(9), 934-948. https://doi.org/10.1287/mnsc.24.9.934

Nachmias, C., \& Nachimias, D. (2004). Research Methods in Social Science (5th ed.). India; Replica

North, D. (1990). Institutions, Institutional change and Economic performance. Cambridge University Press. https://doi.org/10.1017/CBO9780511808678

O'Sullivan, D., Abela, A. V., \& Hutchinson, M. (2009). Marketing performance measurement and firm performance. Evidence from the European high-technology sector. European Journal of Marketing, 43(5/6), 843-862. https://doi.org/10.1108/03090560910947070

Pearce, J., Freeman, E., \& Robinson, R. (1987). The tenuous link between formal strategic planning and financial performance. Academy of Management Review, 12(October), 658-675. https://doi.org/10.5465/amr.1987.4306718

Saunders, M., Lewis, P., \& Thornhill, A. (2007). Research methods for business students (4th ed.). Harlow: Pearson Education.

Thune, S., \& House, R. (1970). Where long range planning pays off: Findings of a survey of formal. Informal Planners, 13(4), 81-87. 
Ugboro, I., Obeng, K., \& Spann, O. (2015). Strategic planning as an effective tool of strategic management in public sector. Evidence from public transit organizations. Sage Journal, 22, 1-43.

UNESCO. (2013). Rankings and Accountability in higher education. Uses and misuses. UNESCO publishing, 7.

Venkatraman, V., \& Grant, J. (1986). Construct measurement in organizational strategy research. A critique and proposal. Academy of Management Review, 11, 71-87. https://doi.org/10.5465/amr.1986.4282628

\section{Copyrights}

Copyright for this article is retained by the author(s), with first publication rights granted to the journal.

This is an open-access article distributed under the terms and conditions of the Creative Commons Attribution license (http://creativecommons.org/licenses/by/4.0/). 